\title{
The New Media as a Viable Alternative to Traditional Film Marketing in Nigeria
}

\author{
Emmanuel Onyeka Ebekue \\ http://dx.doi./org/10.4314/ujah.v19i2.5
}

\begin{abstract}
The changing technological landscape is affecting all dimensions of human endeavour. This paradigm shift is obviously also being experienced in the film industry where the mode of presentation of content has shifted from the mechanical analogue format to the computerized digital format. The effect of this shift is felt not only in the quality of content but also in its mode of access and distribution. Against this backdrop, this study focused on the new media (the Internet) as an alternative film distribution channel in the Nigerian film industry. The study sought to discover the extent online film distribution is becoming realized in the country through surveying undergraduate students of Nnamdi Azikiwe University, Awka with reference to their film accessing and purchasing culture. Situated within the framework of the technological determinism theory, the study was designed as a sample survey. One hundred respondents were randomly sampled from the population while a structured questionnaire was utilized as the data collection tool. Findings showed that the new media is emerging as an important source of accessing Nigerian films among the audience; but that only a small proportion of the viewers, however, pay to download Nigerian films online. It also found that online film distribution could endanger copyright of filmmakers given the audience's seeming indifference to the authorization status of the sites they download films from. The study concluded that a film market built to suit the new media form
\end{abstract}


will serve as a viable alternative to the traditional DVD/VCD film market in Nigeria as long as the challenges of copyright inherent in the Internet are adequately resolved. It was, among others, recommended that film policy in Nigeria should be broadened to capture the imperatives of online distribution of films. Such policy thrusts should be targeted at creating the institutional framework and removing all hiccups towards an efficient online distribution culture in the nation's film industry.

Key words: New media, Internet, film, distribution

\section{Introduction}

The Nigerian film industry Nollywood has become one of the fastest evolving industries in Nigeria. The industry which came to life in the wake of Kenneth Nnebue's movie, Living in Bondage (1992) has become a globally acclaimed brand. The industry occasioned by need and economic depression has blossomed and grown and keeps mutating to adapt to both changes in technology and changes occasioned by competition from surrounding film industries mostly from America and Asia. Nollywood since birthing has been a source of pride to the Nigerian populace and has been a major source of entertainment for the generality of the Nigerians and many other Africans. It is among the few Nigerian brands that enjoy a towering level of patronage from Nigerians and surrounding African countries. This is mostly because of its absolute devotion to telling indigenous stories and bringing to the fore the African narrative.

As a result, it has become a window for selling the African narrative abroad and a major means of exporting the African culture far beyond the shores of Africa. Nollywood has not stopped at these but has also opened windows of opportunities to Nigerians and has become a major source of livelihood to many Nigerians. Recent study has actually shown that apart from agriculture and civil service, Nollywood is the highest employer of labor in the country (Rebecca Moudio, n.p). This 
explains the burgeoned output in the quantity of films churned out from the industry on a yearly basis. Recent rating from the UN shows that Nollywood is the second highest producer of movies globally trailing India's Bollywood (Emmanuel Dandaura, n.p). Nollywood has made tons of stars and celebrities who ply their trade both within and outside the Nigerian geo-space. Many of these celebrities were people who came from the lowest echelons of society and had no hopes of having their names etched on the sands of time. However with the advent of Nollywood, many of these have become superstars, models, celebrities, screen gods and goddesses whose presence people warm up to in major gatherings both within and outside the continent.

However, amidst this success story, Nollywood has however had tons of criticisms thrown at it. It has mostly been accused of peddling shallow and inept contents. Thus Udomisor W.I. and Sonuga A.A. opine: "despite the international attention currently received by Nollywood, the quality of its productions and the content of its stories are still issues that need to be worked on" (33). These criticisms however are not without their reasons which in themselves mostly are valid. However, this is only to be expected from a budding industry completely powered by private investors and hardly protected by the policies of government. It is expected however, that time will advance the industry to outgrow many of the flaws for which it is mostly criticized. More so, Nollywood practice has not been a milk and honey affair. Of all the challenges producers in this nascent industry have had to deal with, marketing seems to be one of the major issues militating against the continued growth of the industry.

Film making is just like any other business venture. Every business investor strives to maximize profit. In line with this, every film maker strives to maximise profit and to be appreciated by consumers of his product. It is therefore pertinent that every film be painstakingly marketed and made available to viewers through whom the film maker realizes his goal of profit making and artist appreciation. Unfortunately, film marketing in Nigeria has become a bottleneck to producers. This is because the Nigerian film market is controlled by a few individuals who 
determine the soul and trend of movie making in the industry. In effect, the average producer is at the whims and caprices of the marketer who determines whose films see the light of the day. Of all the troubles trailing film marketing in the industry, piracy has become the virus that sinks the funds of the Nigerian filmmaker and denies him the happiness and fulfillment that come with making a successful investment. Chisimdi Udoka Ihentuge (n.p) calls it the bane of the Nigerian film industry. This situation is not helped by the advent of the new media (the Internet); in fact, it has aggravated it by way of offering cheap platforms and anonymity to copyright infringers. It is all these that necessitate alternative film market through which the producer can distribute and market his films. With the gradual return of cinema in Nigeria, the hope of alternative film market is surging as the film maker has the option of marketing his movie in the cinema.

However, due to the paucity in the number of available cinema screens in the country, it becomes more pressing to device better alternatives to the conventional Nigerian VCD/DVD film market. In light of the new media culture that has become the trend in communication and virtual marketing; film marketing may have found a more reliable alternative that will be most suiting to the average Nigerian film maker. By embracing the new media, filmmakers would not only benefit from its cost-effectiveness and flexibility, but would also be countering the activities of pirates who have found the new media a cheap and safe tool for their illicit trade. Hence, it is the aim of this research to study the 'New Media' in order to determine its viability as an alternative film market for distributing Nigerian films to global audience. Therefore this research is geared to proffer answer to the following research questions:

1. How popular is the Internet as a source of accessing Nigerian films?

2. What proportion of the viewers pays to download Nigerian films online?

3. How secure is the copyright of filmmakers in the face of online distribution of films? 


\section{The Nature and Form of Nollywood}

The history of film making and screening in Nigeria spans through the colonial period to modern Nigeria. Nollywood has evolved and has become one of the most successful film industries in the world. Uchenna Onuzulike (25) classifies Nollywood history into four different eras namely;

a) The Colonial period which spanned from 1903 to 1960

b) The Independence period which lasted from 1960 to 1972

c) The Indigenization Decree period which spanned from 1972 to 1992

d) The Nollywood period that spans from 1992 till date.

The first film screening in Nigeria took place in 1903 at Glover memorial hall In Lagos. The colonial film unit was set up mostly to aid the British colonialists in administering their territories in the area now called Nigeria. For Ebewo Patrick "the medium was used primarily to educate Nigerians about such issues as health, sanitation, and nutrition" (46). The colonial films were mostly documentaries whose distribution method involved a mobile screening to locals in their respective villages. However, post-independence film era witnessed an attempt by indigenous producers to dominate the film industry in Nigeria. This attempt however would not last long as they faced stiff competition with imported contents from India, China, Philipines etc. The move at indigenizing films in Nigeria failed as the indigenous producers could not compete due to the high cost of producing and developing the celluloid films. The economy was in shambles and the cinema culture which was their main distribution system in Nigeria dwindled due to crime and relative unrest generated by the recessed economy of the 1980s. Articulating the reasons for the quick demise of the cinema culture of the late $20^{\text {th }}$ century Nigeria, Afolabi Adesanya as cited by Abiodun Olayiwola opines:

The economics of celluloid film production and marketing had been the bane of Nigerian filmmakers. Since the commencement 
of commercial film production in the country, and prior to the establishment of Nigeria Film Corporation's lab and sound dubbing studio facilities, production and post-production overheads had to be paid for either in British pounds or US dollars. The resultant effects were two-fold: an inflated budget and a drain on the country's foreign reserves. (58)

With the high cost of developing the celluloid films and the economic downslope which resulted in crimes and dwindled night life, there was an urgent need to find a viable alternative that would be more attainable for the local producers. This in effect motivated the resort to the video technology which was cheaper to make though with an inferior output. Thus the Nollywood era was birthed in the 1992 with the production of Kenneth Nnebue's Living in Bondage (1992). Since the switch from celluloid to video, Nollywood has boomed and continues to gain relevance with every passing time. According to Franco Sacchi,

The production of feature-length films made on shoestring budgets for the video market went from a few titles a year in the early 90 s to several dozens a week by 2005 . Against all odds a vibrant creative industry had taken off in the midst of economic instability. (42)

The Nollywood era thus can be categorized into three;

i. The Discovery/experimentation era

ii. The crisis era

iii. The Resurgence

This categorization is made based on the internal activities of the industry from the point of its discovery to modern times. The Discovery era dates from the point of Nollywood's birthing with Keneth Nnebue's Living in Bondage in 1992 to about the year 2005. The Nollywood of this era was the emergent Nollywood driven by passion and excitement. Its stories were mostly indigenous and as such enjoyed overwhelming patronage. Michael Correy (137) describing the Nollywood of this era 
opines "Each film is very low budget, straight to video format, and sold at an inexpensive price. This allows Nigerians whose typical income is one dollar a day, to watch an affordable film within their homes". However the technology was poor as it was an experiment being conducted with the VHS camera. As a result, the cinematography was quite poor, and pictures were shaky. However, these notwithstanding, the market boomed and the system waxed as the African market thrilled at the notion of having itself mirrored by the emergent industry. However, just like in world history, Nollywood dark days would come with the new millennium as the industry became proliferate with titles and contents watered. It was the saturation point for the new industry as the feel of newness quietly sifted away with the recycling of themes and story lines. Jonathan Haynes (54) lamenting the wane opines "by 2007 Nollywood was in a crisis of overproduction. The market was so saturated; it was difficult for any film to turn a decent profit". These were the crisis days of Nollywood.

The young industry was under a fitness trial from both within and outside the national space. One of the most virulent ailments that have trailed the industry since then is piracy. The virility of the industry has been marred by the activities of pirates who illicitly acquire films, mass produce them and sale in the market. Therefore when a film is produced, it competes with its shadow copies littered all around the market environment. The effect is usually heavy on the investor who most times ends up not realizing the return on his investment. This era in Nollywood's evolution was driven by the drive for business and less of artistic invention. As a result, the emphasis was not on the quality of films being churned out but on the quantity and this greatly diminished the image of the industry in film discuss circles around the world.

The need to resurge quality and re-invent the art lacking in the copious production of the young industry gave birth to the "New Nollywood" championed by the likes of Kunle Afolayan, Tunde Kelani, Izuu Ojukwu, Obi Emelonye, Emem Isong, Omoni Oboli and a host of others. Ezinne Igwe (1269) discussing the new cinema movement opines: "Production drive and purpose are becoming increasingly incentivized by 
creativity rather than profit which makes the divide between old and new Nollywood". Thus the new Nollywood has striven to overcome the bottle neck of conventional film marketing in Nigeria and as such has reinvented the cinema release distribution system. Films are first released on cinema screens both within and outside Nigeria, before they are sold to the cable distribution companies and the conventional marketers who sale on DVDs. By so doing, the film maker recuperates his money and takes time to market his product before they are pounced upon by greedy pirates who diminish his return on investment. However, the cinema system is not without its own challenges. The paucity of screens in the country makes it difficult for most films produced to find their ways to the cinema. Most times, the producers will have to queue their films for upwards of one year before the film can be screened in the cinema. This on its own poses a major challenge to the investor who hopes to get back his money within a very short time. With the advent of the new media and internet system in the country, more avenues have begun to spring up through which films are being distributed in the country. The most popular of these platforms are Youtube, IrokoTv, Real NollyTv, IbakaTv and a host of others.

\section{Film Distribution System in Nigeria}

Just as the Nigerian film industry emerged as a child of necessity, its marketing industry also evolved as a child of necessity. The Traditional film distribution network in Nigeria is basically domiciled in the different electronic markets located in different parts of Nigeria. These markets serve mostly as distribution centers for the films from where the films are accessed by local vendors and rental shop operators. Basically, there are four major distribution centers in the country which are all located within the western and Eastern Nigeria geo-zones. There is the Alaba and Idumota distribution centers all located in Lagos state and the Onitsha and Aba distribution centers located in Anambra and Abia states respectively. These four cardinal locations serve as the film distribution anchors from where these films are distributed and made available to local consumers. The Northern Nigeria is serviced by the Kano film 
market which serves as the hub for film distribution in the area. These distribution centers are usually run by a number of business men known as marketers. These marketers mostly are also producers who make and market their movies in addition to marketing others that are produced by non-marketer producers.

\section{The New Media and the Nigerian Experience}

Bailey Socha and Barbara Eber-Schmid define 'new media' as "a $21^{\text {st }}$ Century catchall term used to define all that is related to the internet and the interplay between technology, images and sound". The $21^{\text {st }}$ century has witnessed a wave of evolution in science and technology and has soared mostly in the area of information technology. In effect, there has been a technological revolution geared towards making life less cumbersome and making the world better connected. Networking has become very vital and relevant to modern existence. Thus, the world is shrinking into a liminal space that is on a continuous morph. The result is a super network of life that has rendered physical distance insignificant. This emergent system that has invalidated impossibilities created by geophysical distance in human relations is what is described as the new media.

Barbara and Bailey are also of the opinion that the "new media is more apt to describe the network of networks that overwrites traditional relationships in exchange for new ones" (n.p). Thus the New media has come to promote a virtual community of humans who interact and socialize on a limbo platform powered by micro technology. Marshall McLuhan in 1964 preempted a global village in which he predicted the internet as an "extension of consciousness". Thus he predicts that this extension of consciousness would result to a global village. T. Gibson and S.J. Murray describe this global village as a situation where "...human beings are increasingly connected by electric (or electronic) technologies, which virtually eliminate the effects of space and time so that the globe contracts into one interconnected, metaphorical 'village' (312). With the advent of the internet, this metaphor 'global village' has become a noon day reality and the world has become interlinked. 
Information has become supercharged in that it travels at the speed of light. The effect is awesome both on the economy and politics of the world. Thus Mahmuda Swarna opines:

Increased speed of communication and the ability of people to read about, spread, and react to global news quickly, forces us to become more involved with one another from various social groups and countries around the world and to be more aware of our global responsibilities. (n.p)

Thus with the internet the world has become a virtual community were people of like minds who are bound by distances in space meet, interact and revel in each other's ideas. Ideas are shared and made available to a vast number of people beyond the imaginations of the traditional media. Thus Alan Kluver espouses the thought that "the emerging media give individuals access to vast amounts of information, bypassing traditional media outlets" (506). The internet as such has made it possible for the emergence of the social media which in its most unique form allows for spontaneous and instantaneous interactions between people. These networks of social communities enhance rapid interrelation among people of the world. The result is a paradigm shift both in the political, religious, social and market economies of the globe.

Nigeria is however not left out of this movement. The internet was introduced in Nigeria in 1995 and has become entrenched in the Nigerian life. Its usage and popularity grew with the introduction of the mobile phone system in 2002 during president Obasanjo's administration. Since then, the internet has become entrenched in the daily living of most Nigerians. Though it is mostly popular among the youths, it has however become entrenched in every facet of business experience in Nigeria ranging from banking to online market spaces which have become the more utilized thanks to the social media. With the introduction of social media apps like Facebook, Whatsapp, Instagram, twitter and Youtube, the country has further become shrinked into a micro space carried around in phones and other gadgets that have the ability to link up to the pool of individual and public networks 
scattered all around the world. Thus, communication has become very easy as people can access information from every part of the country they are in. Social media has also enhanced the business experience of most Nigerians as most entrepreneurs have their business located right inside their homes. In effect, people transact businesses without having to own shops or leave the comfort of their homes. Amongst the leading online market spaces are Jumia, Konga, Jiji and Olx. Facebook, Instagram and Twitter have also made it very easy for budding entrepreneurs to market their goods and services. The Nigerian movie industry has also benefited immensely from this window of opportunities as advert and publicity have become easier. Films are advertised right from the first day of shoot on social media platforms. Thus through online publicity and advertisements, the film consciousness of most Nigerians are better enhanced. Among the many benefits of the internet to the film maker, the ability to market films online is the most thrilling. This however is the crux of the researcher and will be better discussed at the point of analysis.

\section{Theoretical Framework}

The technological determinism theory helps us to conceive the subject of this study from a theoretical viewpoint. This is "a reductionist theory that presumes that a society's technology drives the development of its social structure and cultural values." It has been "defined as an approach that identifies technology, or technological advances, as the central elements in processes of social change" (Croteau \& Oynes, 2003).

The term is believed to have been coined by Thorstein Veblen (1857-1929) an America sociologist. Proponents of technological determinism conceive technology as a very powerful force whose influence remains constant irrespective of how humans use or can use it. Thus, they view technology as the foundation of all human activities instead of considering is as a component of a larger spectrum of human activities (McQuail, 2010). However, technological determinism was first applied to communication by the Canadian scholar, Marshal McLuhan, who states that communication technology shapes how we as 
individuals in a society think, feel, act, and how the society operates as we move from one technological age to another (Mcluhan as cited in Alao Ayotunde, 97). Technological determinism theory holds that individuals do not have much free will at all. Whatever society as a whole is using to communicate, individuals too will use to communicate. Therefore they will adapt to the medium common in the society so that they can send and receive messages like everyone else (Griffin, 2000). The individual interpretation, according to Mcluhan, is that we learn, feel and think the way we do because of the messages we received through the current technology that is available. The radio required of us to only listen and develop our sense of hearing. On the other hand, television engages both our hearing and visual senses. We then transfer those developed senses into our everyday lives and we want to use them again. Therefore "the medium is then our message."

Applied to this study, the theory helps us to view the digital cum online technology as the determinant of the mode of distribution of media content including films. Thus, as the new media technology increasingly supplants (overtakes) the traditional media (VCD, DVD etc), it (the new media) begins to exert a determining (defining) effect on how people access media products. Thus, the mode of distribution of media content begins to experience gradual shift from the mode dictated (or determined) by the older technology to that determined by the newer technology - in this case the new media. State differently, our lives, activities and preferences, to a large extent, depend on the technology available at any time in question. Thus, our mode of accessing films would be dependent on the technology that prevails in the realm of filmmaking and content encoding at any point in time. 


\section{Data Presentation and Analysis}

\section{Table 1}

Response Rate

\begin{tabular}{|l|c|c|}
\hline & Frequency & Percentage \\
\hline No. Returned & 88 & $88 \%$ \\
\hline No. Not Returned & 12 & $0 \%$ \\
\hline Total & $\mathbf{1 0 0}$ & $\mathbf{1 0 0 \%}$ \\
\hline
\end{tabular}

Out of the total of 100 questionnaire copies distributed, 88 representing $88 \%$ were recovered while 12 representing $12 \%$ were not recovered. Thus, $88 \%$ response was recorded while the casualty rate was $12 \%$.

\section{Demographic Variables}

Two demographic variables were measured; age and gender of the respondents. Data generated from these are presented in Figures 1 and 2 below.

\section{Figure 1}

\section{Respondents' Age Brackets}

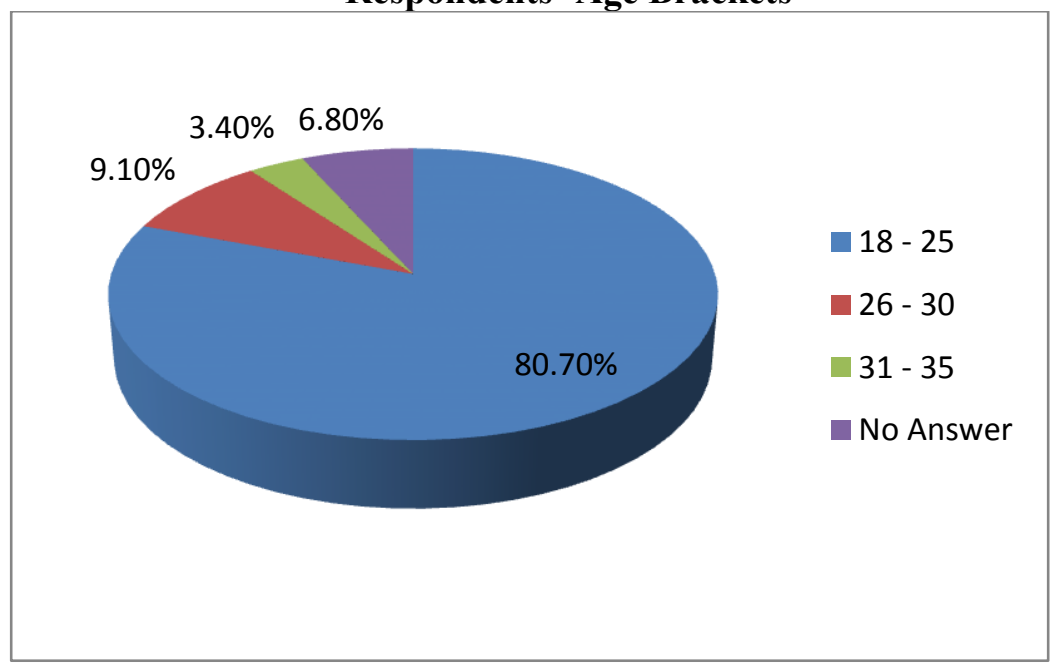


Figure 1 shows that $80.7 \%$ of the respondents were $18-25,9.1 \%$ were $26-30,3.4 \%$ were $31-35$, while $9.1 \%$ did not give their age. Therefore, majority of the respondents were $18-25,31-35$ years was the least featured age bracket.

Figure 2

Respondents' Gender

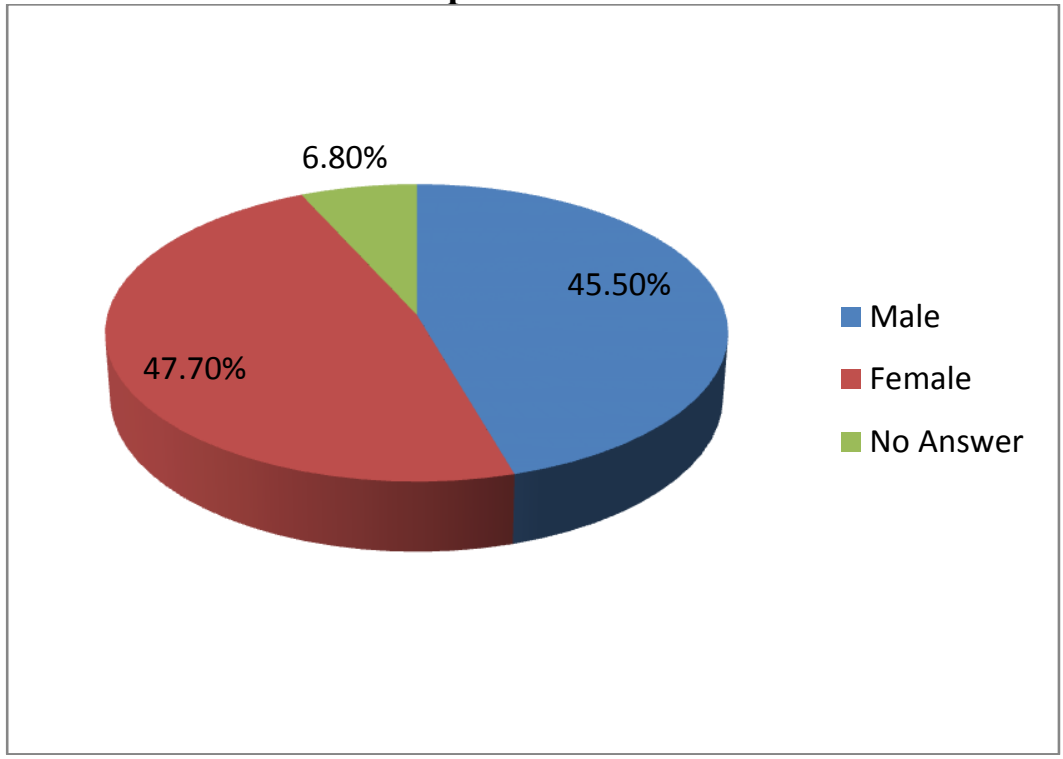

Figure 2 shows that $47.7 \%$ of the respondents are female, $45.5 \%$ male while $6.8 \%$ did not indicate there gender. The female respondents are more in number. 


\section{Film Viewership}

Table 2

Respondents' Viewing of Nigerian Films

\begin{tabular}{|l|c|c|}
\hline & Frequency & Percent \\
\hline Yes & 82 & 93.2 \\
No & 6 & 6.8 \\
Total & $\mathbf{8 8}$ & $\mathbf{1 0 0 . 0}$ \\
\hline
\end{tabular}

Table 2 shows that $93.2 \%$ of the respondents view Nigerian films, while $6.8 \%$ do not. Thus, almost the entire respondents watch Nigerian films, testifying to the popularity which local films are enjoying among the populace.

Table 3

Respondents Frequency of Viewing of Nigerian Films

\begin{tabular}{|l|c|c|}
\hline & Frequency & Percent \\
\hline Very Often & 14 & 15.9 \\
Often & 29 & 33.0 \\
Rarely & 30 & 34.1 \\
Very Rarely & 13 & 14.8 \\
No Answer & 2 & 2.3 \\
Total & $\mathbf{8 8}$ & $\mathbf{1 0 0 . 0}$ \\
\hline
\end{tabular}

Table 3 shows that $15.9 \%$ of the respondents view Nigerian films very often, $33 \%$ of the respondents view them often, $34.1 \%$ view them rarely while $14.8 \%$ view them very rarely. However, $2.3 \%$ of the respondents did not indicate the frequency of their viewing. What this shows is that about $50 \%$ of Nigerians enjoy Nigerian films as their main source of relaxation while about $50 \%$ are still somewhat indifferent towards it. 
Mode of Film Access

Table 4

Respondents' Mode of Access to Nigerian Films

\begin{tabular}{|l|c|c|}
\hline & Frequency & Percent \\
\hline Cable & 40 & 45.5 \\
Online & 6 & 6.8 \\
DVD & 21 & 23.9 \\
Peer-to-Peer Transfer via & 18 & 20.5 \\
Digital Devices & & \\
No Answer & 3 & 3.4 \\
Total & $\mathbf{8 8}$ & $\mathbf{1 0 0 . 0}$ \\
\hline
\end{tabular}

Table 4 shows that $45.5 \%$ of the respondent's access Nigerian movies on cable stations, $23.9 \%$ access them on DVD machines, $20.5 \%$ access them through peer to peer transfer on mobile devices while $6.8 \%$ view them online. The indication is that most of the respondents access the Nigerian films on cable stations.

Table 5

Respondents' Platform of Viewing Nigerian Films

\begin{tabular}{|l|c|c|}
\hline & Frequency & Percent \\
\hline Laptop and Phones & 37 & 42.0 \\
Cable TV & 29 & 33.0 \\
DVD & 18 & 20.5 \\
No Answer & 4 & 4.5 \\
Total & $\mathbf{8 8}$ & $\mathbf{1 0 0 . 0}$ \\
\hline
\end{tabular}

Table 5 shows that $42 \%$ of the respondents view Nigerian films via laptops and phones, $33 \%$ view them via cable TV, $20.5 \%$ view them through DVD, while $4.5 \%$ gave no answer regarding their major source $f$ 
viewing the films. Thus, over $40 \%$ watch films on laptop and phones while DVD is the least used platform for viewing films among the respondents.

\section{Table 6}

Respondents' Purchase of Nigerian Films in DVDs

\begin{tabular}{|l|c|c|}
\hline & Frequency & Percent \\
\hline Yes & 25 & 28.4 \\
No & 60 & 68.2 \\
System & 3 & 3.4 \\
Total & $\mathbf{8 8}$ & $\mathbf{1 0 0 . 0}$ \\
\hline
\end{tabular}

Table 6 shows that $28.4 \%$ of the respondents still buy Nigerian films in DVD format, while $68.2 \%$ do not even as $3.4 \%$ evaded the question or were undecided. The implication is that about $68 \%$ of the Nigerians who watch Nigerian films no longer buy the films in DVD format; they access the films through other means.

\section{Table 7}

Respondents' Frequency of Purchase of Nigerian Films on DVDs

\begin{tabular}{|l|c|c|}
\hline & Frequency & Percent \\
\hline Very Often & 7 & 8.0 \\
Often & 15 & 17.0 \\
Rarely & 16 & 18.2 \\
Very Rarely & 11 & 12.5 \\
No Answer & 39 & 44.3 \\
Total & $\mathbf{8 8}$ & $\mathbf{1 0 0 . 0}$ \\
\hline
\end{tabular}


Table 7 shows that $8 \%$ of the respondents buy Nigerian films in DVD format very often, $17 \%$ buy them often, $18.2 \%$ rarely buy them while $12.5 \%$ of the respondents very rarely buy them. The implication is that less than $50 \%$ of the ones who still buy Nigerian Films in DVD format are frequent buyers.

\section{Table 8}

Respondents' Streaming/Downloading of Nigerian Films

\begin{tabular}{|l|c|c|}
\hline & Frequency & Percent \\
\hline Yes & 30 & 34.1 \\
No & 53 & 60.2 \\
No Answer & 5 & 5.7 \\
Total & $\mathbf{8 8}$ & $\mathbf{1 0 0 . 0}$ \\
\hline
\end{tabular}

Table 8 shows that $34.1 \%$ of the respondents stream/download Nigerian films, $60.2 \%$ do not, while $5.7 \%$ did not indicate if they stream or not. Thus, streaming/downloading occurs only among less than $35 \%$ of the respondents.

Table 9

Respondents' Online Purchase of Nigerian Films

\begin{tabular}{|l|c|c|}
\hline & Frequency & Percent \\
\hline Yes & 21 & 23.8 \\
No & 62 & 70.5 \\
No Answer & 5 & 5.7 \\
Total & $\mathbf{8 8}$ & $\mathbf{1 0 0 . 0}$ \\
\hline
\end{tabular}

Table 9 shows that $23.8 \%$ of the respondents purchase Nigerian films online while $70.5 \%$ do not. However, $5.7 \%$ did not supply any answer in this regard. A combined reading of the data in Tables 8 and 9 shows that 
a little over $10 \%$ difference existed between the number that download films online and the number that pay for such films.

Table 10

Respondents' Frequency of Downloading Nigerian Films

\begin{tabular}{|l|c|c|}
\hline & Frequency & Percent \\
\hline Very Often & 4 & 4.5 \\
Often & 12 & 13.6 \\
Rarely & 15 & 17.0 \\
Very Rarely & 23 & 26.1 \\
No Answer & 34 & 38.6 \\
Total & $\mathbf{8 8}$ & $\mathbf{1 0 0 . 0}$ \\
\hline
\end{tabular}

Table 10 shows that $4.5 \%$ of the respondents download Nigerian films very often, $13.6 \%$ download often, $17 \%$ stream Nigerian films rarely while $26.1 \%$ stream them very rarely. The indication is that the number of Nigerians who access Nigerian films online is still below $45 \%$ of its audience.

Table 11

Respondents' Consciousness of the Authorisation

Status of Sites They Download Films From

\begin{tabular}{|l|c|c|}
\hline & Frequency & Percent \\
\hline Yes & 26 & 29.5 \\
No & 45 & 51.1 \\
No Answer & 17 & 19.3 \\
Total & $\mathbf{8 8}$ & $\mathbf{1 0 0 . 0}$ \\
\hline
\end{tabular}

Table 11 shows that $29.5 \%$ of the respondents are conscious of the authorization status of the sites they download films from while $51.1 \%$ of 
the respondents are not conscious about the legitimacy of the sites they stream/download movies from. The implication is that the awareness rate is still low vis-à-vis authorization status of sites that offer film download.

\section{Analysis of Research Questions}

Research Question 1: How popular is the Internet as a source of accessing Nigerian films?

Data in Table 3 to 9 show that while Internet has not become the major source of accessing films among the respondents, it is surely gaining some popularity with Table 8 indicating that $34.1 \%$ do in fact download films. Data in Table 9 show that more than $18 \%$ carryout such download very often or often. Based on the foregoing, it may be stated in answer to the first research question that the Internet is emerging as an important source of accessing Nigerian films among the audience.

Research Question 2: What proportion of the viewers pays to download Nigerian films online?

Data in Table 9 shows that $23.8 \%$ of the respondents said they pay for films online. The foregoing indicates that close to a quarter of the respondents make online film purchase. Consequently, the second research question is answered by stating that only a small proportion of the viewers pay to download Nigerian films online.

Table 11 shows that only $29.3 \%$ of the respondents are mindful of the authorization status of the sites from where they download Nigerian films. This implies that their downloading of films could amount to copyright infringement given that a lot of sites now offering Nigerian films are unauthorized. Based on the foregoing, it is stated in answer to the third research question that online film distribution could endanger copyright of filmmakers given the audience's seeming indifference to the authorization status of the sites they download film from. 


\section{Conclusion}

The shift in technological paradigm amounts to a corresponding shift in market form. The Nigerian film industry has metamorphosed in time and keeps evolving to meet the needs of the time. The traditional DVD/VCD market no longer meets the need of a typical Nigerian film maker as its permutations defy the return on investment. It is therefore necessary that the marketing strategy and platform change so as to favor the investor whose grand goal is to make profit. This research thus was motivated by this and in effect has conducted an audience based inquiry to determine the viability of the New Media as an alternative to the traditional film market in Nigeria. The findings show that the new media technology has become very popular among Nigerians. The findings also suggest that most Nigerians prefer to play there movies on the digital mobile devices. The results equally indicate that online downloading of films is becoming a popular alternative among the viewers, though the rate of online purchase is still low. The researcher therefore concludes that a film market built to suit the new media form will serve as a viable alternative to the traditional DVD/VCD film market in Nigeria as long the challenges of copyright inherent in the Internet are adequately resolved.

\section{Recommendations}

Based on the findings of this study and other observations by the researcher, the following recommendations are found relevant:

i. Film policy in Nigeria should be broadened to capture the imperative of online distribution of films. Such policy thrusts should be targeted at creating the institutional framework and removing all hiccups towards an efficient online distribution culture in the nation's film industry.

ii. The Nigerian Copyright Act should be amended to reflect the realities of the Internet-based intellectual property including film. This is one way of encouraging filmmakers to utilize the Internet for distribution of their products. 
iii. There should be continuous sensitization of the audience towards growing the culture of online film consumption. This sensitization should include the need for verifying the authorization status of the sites from which films are downloaded.

a. Future repeat of this study should include filmmakers and marketers as study population so as to capture their experiences and opinions regarding the viability, challenges and prospects of online film distribution in the country.

\section{Emmanuel Onyeka Ebekue}

Department of Theatre and Film Studies

Nnamdi Azikiwe University, Awka eo.ebekue@unizik.edu.ng

\section{Works Cited}

Asika, Nnamdi. Research Methodology in Behavioural Sciences. Lagos, Longman Plc, 1991.

Bankole, Olaniyi, M. and Babalola, Sobowale, O. "Internet Use Among Undergraduate Students of Olabisi Onabanjo University, Ago Iwoye, Nigeria. Library Philosophy and Practice (e-journal), Paper 812, 2012.

Correy, Michael. "Nollywood: A Socially Conscious Cinema?" Black

Camera Vol. 22.2 (2008): 137-138.

Dandaura, Emmanuel. "Book Review: Trends in Nollywood: A Study of Selected Genres." 2014. Nationsl Institute For Cultural Orientation. 24 October 2017 <http://www.nico.gov.ng/index.php/category-list-2/1301-bookreview-trends-in-nollywood-a-study-of-selected-genres $>$. 
Ekweli, Obiageli, V. "Uses of Internet Among Undergraduates in Anambra State (Unpublished Master's thesis) Nnamdi Azikiwe University, Awka, Nigeria, 2014.

Ebewo, Patrick. "The Emerging Video Film Industry in Nigeria:

Challenges and Prospects." Journal of Film and Video 59.3 (2007): 46-57.

Fasae, John, K. and Aladeniyi, Francis R. Internet Use by Students of

Faculty of Science in two Nigerian universities. Library

Philosophy and Practice 2012, 2014. http://unllib.unl.edu/LPP/, Accessed October 272017.

Gibson, T. and S.J. Murray. "Global Village." Encyclopedia of Media and Communication. Ed. M. Danesi. Toronto: University of Toronto Press, 2012. 312 - 313.

"Global Village." Wikipedia. 13 July 2017 <https://en.wikipedia.org/wiki/Global_village>.

Haynes, Jonathan. "“New Nollywood": Kunle Afolayan." Black Camera Vol. 5, No. 2 (2014): 53-73.

Igwe, Ezinne. "Structure and Power Struggle in Contemporary Nollywood: An Ethnographic Evaluation." International Journal of Social, Behavioral, Educational, Economic, Business and Industrial Engineering Vol:11, No:6.1266 - 1279 (2017).

Ihentuge, Chisimdi Udoka. "Thereof, The Nigerian Copyright Act and the Menace of Piracy in Nollywood: Contemporary Realities." 14 July 2015. National Institute for cultural Organisation. 24 October 2017

<http://www.sonta.nico.gov.ng/index.php/papers/350-ihentugechisimdi-udoka-the-nigerian-copyright-act-and-the-menace-ofpiracy-in-nollywood-contemporary-realities-thereof>.

Kluver, Alan. "The Logic of New Media in International Affairs." Sage Vol. 4 (2002): 499 - 517.

Mba, Emmanuel. " Nigerian Movies: Movies, Culture, Democracy and National Development. Paper Presented by the Director-General of the National Film and Video Censors Board, Mr. Emeka Mba at the Young Achievers' Conference held in Abuja, March 31st 2006. 
McLuhan, Marshal. Understanding the Media: The Extensions of Man.

New York, McGraw-Hill, 1962.

McQuail, Dennis. Theories of Mass Communication (6th ed.). Beverly Hills, CA, Sage Publications, 2010.

Mgbejume, Onyero. Film in Nigeria: African Media Monograph Series.

Nairobi: African Council for Communication Education, 1996.

Moudio, Rebecca. "Nigeria's film industry: a potential gold mine?" May

2013. Africa Renewal. 23 October 2017

$<$ http://www.un.org/africarenewal/magazine/may-

2013/nigeria\%E2\%80\%99s-film-industry-potential-gold-mine>.

Olayiwola, Abiodun. "The Tragedy of the Nigerian Film Industry."

Journal of Film and Video Vol. 59.3 (2007): 58 - 61.

Onuzulike, Uchenna. "Nollywood: The Birth of Nollywood: The

Nigerian Movie Industry ." Black Camera (2007): 25-26.

Sacchi, Franco. "Nollywood cleans up." The World Today Vol. 69.5

(2013): 42-43.

Socha, Bailey and Barbara Eber-Schmid. "What is New Media?" 2014.

New Media Institute. 7th July 2017

<http://www.newmedia.org/what-is-new-media.html>.

Solo-Anaeto, Margaret. "Exploring Social Media as Channels for

Sustaining African Culture." International Journal of

Humanities and Social Science (Online) (2015): 37 - 42.

Swarna, Mahmuda. "Impact of New Digital media on Globalisation." 23

October 2013. SCRIBD. 13 July 2017

$<$ https://www.scribd.com/doc/178441381/Impact-of-New-

Digital-Media-on-Globalization>.

Udomisor, W.I. and A A Sonuga. "Content Analysis of Programs

Produced by Nollywood Particularly on Africa Magic: DSTV."

Research on Humanities and Social Sciences (Online) 2.11

(2012): 27 - 34. 